\title{
HAZOP Study and Risk Reduction Strategy for Herbal Processing Industry
}

\author{
Kamarizan Kidam ${ }^{\text {* }}$, Mohamad Fazli Masri², Nabila Salleh², Mimi H.Hassim², Nuramalia Adzman², Siti \\ Suhaili Shahlan ${ }^{2}$, Hamidah Kamarden ${ }^{2}$ \\ ${ }^{1}$ UTM-MPRC Institute for Oil \& Gas, Universiti Teknologi Malaysia, 81310 Johor Bahru, Johor, Malaysia \\ ${ }^{2}$ School of Chemical and Energy Engineering, Faculty of Engineering, Universiti Teknologi Malaysia, 81310 \\ Johor Bahru, Johor, Malaysia. \\ *Corresponding Author: kamarizan@utm.my
}

\author{
Article History \\ Received: Jan 15, $2018 \quad$ Received in revised form: Nov 7, 2018 Accepted: Nov 18, 2018 Published: Nov 30, 2018
}

\begin{abstract}
Herbal processing industries in Malaysia grow very rapidly in the recent years. Malaysia has a promising potential and huge marker demand on herbal medicine, as an alternative to the conventional medicine. This is supported by the abundance availability of various biological heritage and herbal corps, as well as the subsistence of herbal processing facilities in the country. Despite the rapid growth of herbal processing industries in Malaysia, safety and health compliance issue should not be compromised. Every aspect related to personnel and process safety shall be complied as required under the Occupational Safety and Health Act 1994. Improper handling of critical processing unit operation can lead to major accident such as fire and explosion. However, knowledge concerning process safety in herbal processing industry is still lacking. The objective of this study is to recommend a safer practice in herbal processing industry, by performing hazard and operability study (HAZOP) as a tool to propose possible design solution based on process safety hierarchy perspective. As a result, several risk reduction strategies for critical equipment were managed to be proposed and classified according to process safety hierarchy. This study will finally discover the element of knowledge 'safe by design' for process and equipment to be enhanced into the herbal processing knowledge and technology development.
\end{abstract}

Keywords: Process safety; herbal processing industry; occupational safety and health; process safety hierarchy; HAZOP.

\subsection{INTRODUCTION}

Malaysia is rich with various natural resources and biodiversity and globally recognized as a country that largely contributes to the herbal based product industry [1]. The demand for processed herbal is significantly high in which the latest statistic shows that the market value of the herbal industry in Malaysia is projected to reach RM32 billion in 2020, with the annual growth rate between 8 to 15\% [2]. The increase of demand among Malaysians towards herbal medicine is due to several factors including the failure of modern treatment, as an alternative to the conventional medicine as well as herbal medicines are not rigorously regulated by the Drug Control Authority of Malaysia $[3,4]$. The World Health Organization reported that about two-thirds and 50 to $80 \%$ of the population in developed and developing countries are using traditional and complementary medicine as an alternative medicine [5].

Eurycoma longifolia (known as Tongkat Ali), Citrus hystrix (known as Limau Purut) and Virgin Coconut Oil (VCO) are among the broadly produced herbs in Malaysia, used for health supplement, natural cosmetic, superior cooking oil and potent herbal medicine [6]. The development of herbal processing industry in Malaysia especially in small and medium enterprises (SMEs) shown a good sign of economic development. Despite the rapid growth of herbal processing industries in Malaysia, the commitment towards safety and health matters must be in place in order to get good balance between productivity and employee's safety, health and welfare. Improper handling of processing unit operation such as boiler, pressure vessel, centrifuge, spray dryer and hazardous solvents can lead to accident such as fire, explosion and chemical spillage. Kletz discussed the aftermath of disastrous disasters involving chemical process industries including the 
Flixborough, Seveso, and Bhopal accidents, which are due to the lack of safety and health consideration, hence resulting to fatalities, occupational disaster, process failure, equipment damage as well as loss of productivity [7].

The importance of having safer operation is essential to prevent incident from happening by making the knowledge associated with particular herbal processing is available. However, nowadays knowledge related to process and equipment safety is very limited for public and industry references which lead to inability to manage the risk and hazard as well as preparing adequate control measure. In term of technology development and advancement, herbal processing technology is still not commercialized hence causing shortcomings in the industry e.g. - unstable process and limited technical knowledge due to competitiveness and secrecy in the ingredients and formulations. Further enhancement is required to improve the process stability and create safer operation in the future.

\subsection{HERBAL PROCESSING TECHNOLOGY}

Value added processing technology for herbs and medical plants are essential for commercialisation purpose. The first step in value addition of medical plants bio resources is the production of herbal drug preparation, which is extraction of medical plant using various methods, ranging from simple traditional technologies to advanced extraction techniques. The basic parameters influencing the quality of an extract are the plant parts used as the starting material, the solvent used for extraction, the extraction technology and the crude-drug extract ratio. As reported by Handa et al., the use of appropriate extraction technology, plant material, manufacturing equipment, extraction method and solvent are certainly influencing in producing a good quality extract. Table 1 presents the comparison among the existing extraction methods for natural extracts [8].

Table 1. The comparison among the existing extraction methods for natural extracts

\begin{tabular}{ccccc}
\hline Technology & Solvent & Time & Pressure & Temperature $\left({ }^{\mathbf{0}} \mathbf{C}\right)$ \\
\hline Solvent Extraction & Ethanol & 3 hours & $\begin{array}{c}\text { Ambient } \\
\text { atmosphere }\end{array}$ & Boiling point \\
\hline Water Extraction & Distillate Water & 2 hours & $\begin{array}{c}\text { Ambient } \\
\text { atmospher }\end{array}$ & Boiling point \\
\hline Soxhlet & Dichloromethane & 16 hours & $\begin{array}{c}\text { Ambient } \\
\text { atmosphere }\end{array}$ & Boiling point \\
\hline Steam Distillation & Steam & 2 hours & $2-4$ bar & Boiling point \\
\hline Sonication & Dichloromethane & 30 minutes & $\begin{array}{c}\text { Ambient } \\
\text { atmosphere }\end{array}$ & Room temperature \\
\hline $\begin{array}{c}\text { Supercritical Fluid } \\
\text { Extraction }\end{array}$ & Carbon Dioxide & $30-60$ minutes & $74-150$ bar & $>30$ \\
\hline Phytonic & Tetrafluoroethane & $30-60$ minutes & $4-10$ bar & Room temperature \\
\hline
\end{tabular}

In order to extract medical ingredients from plant material, the steps involved are size reduction, extraction, filtration, concentration and drying. The general techniques of medical plant extraction include maceration, infusion, percolation, digestion, decoction, hot continuous extraction (Soxhlet), aqueous-alcoholic extraction by fermentation, counter-current extraction, ultrasound extraction (Sonication), supercritical fluid extraction, and phytonic extraction which is using hydro fluorocarbon solvents [8]. Successful determination of biologically active compounds depends on the type of solvent used in the extraction procedure. The choice of solvent is influenced by what is intended with the extract. Among the solvents that can be used in the extraction process are water, ethanol, methanol, chloroform and acetone.

\subsection{SAFETY ISSUES IN HERBAL PROCESSING INDUSTRY}

Harjo et al. and Aziz et al. discussed on the optimization of process development and the available herbal processing technology $[9,10]$. The process and technology development is important to meet a continuously increasing demand, shorter production time and cost reduction in herbal processing industries. Athimulam et al. in their works studied the economic viability of the production scheme for Tongkat Ali extraction technology focusing on the cost effective operation [11]. Despite of the process and technology development, knowledge discussing the process safety in herbal processing is still much lacking. Process safety concept was first introduced following the Seveso and Flixborough disasters. The principle of process safety management (PSM) is to make the plant owner to be responsible in managing the process hazards in their plant [12]. The herbal processing industry is not exempted, particularly due to the use of hazardous solvent and dangerous machinery. Improper handling of hazardous solvent and operating equipment can lead to unwanted accidents. 
In Malaysia, requirement to implement process safety is still voluntary. The study carried out by Kidam et al. shows that only chemical process industry partly implements selected PSM elements while majority of the industries are neglecting the PSM practices, including herbal process industry [13]. Herbal processing industries are obviously involved hazardous process condition, machinery and chemicals, but the operation so far is conducted without adequate safety consideration. Referring to Table 1, with the used of hazardous material and process condition, CCPS has described the possible operational deviation for related equipment for herbal processing industries and summarized as Table 2 [14].

Table 2. Failure Scenarios for Process Industry [19]

\begin{tabular}{|c|c|c|}
\hline Equipment & $\begin{array}{l}\text { Operational } \\
\text { Deviation }\end{array}$ & $\begin{array}{c}\text { Possible Unwanted } \\
\text { Event }\end{array}$ \\
\hline \multirow[t]{2}{*}{ Separation (centrifuge) } & Overpressure & Fire and explosion \\
\hline & Loss of Containment & Chemical spillage \\
\hline \multirow[t]{3}{*}{ Vessel } & Overpressure & Fire and explosion \\
\hline & High Temperature & Fire and explosion \\
\hline & Loss of Containment & Chemical spillage \\
\hline \multirow[t]{2}{*}{ Dryer } & Overpressure & Fire and explosion \\
\hline & High temperature & Fire and explosion \\
\hline \multirow[t]{4}{*}{ Piping } & Overpressure & Fire and explosion \\
\hline & High Temperature & Fire and explosion \\
\hline & Loss of containment & Chemical spillage \\
\hline & Wrong Composition & Runaway reaction \\
\hline \multirow[t]{2}{*}{ Heat Transfer equipment } & Overpressure & Fire and explosion \\
\hline & High temperature & Fire and explosion \\
\hline
\end{tabular}

\subsection{RESEARCH APPROACH}

In this study, hazard identification and risk assessment for herbal processing industries is conducted using the well know approach of the hazard and operability (HAZOP) study. The method used for the HAZOP analysis is based on Nolan in his handbook Application of HAZOP and What-If Safety Review to The Petroleum, Petrochemical and Chemical Industries [15]. HAZOP technique systematically analyses system nodes and defines qualitatively how operational deviations could occur, and whether design changes, revising operating procedures or adding on control measures are required to reduce or eliminate the consequences [16]. The main feature of HAZOP is the use of guideword and parameter to derive the operational deviation. HAZOP method has been used due to the tool capability to identifying hazard and proposed the control measure. HAZOP is an experience based analysis and this method is widely used and globally recognized especially in chemical process industries. In this analysis, the hazard is identified by means of on-site observation, previous upset and maintenance record, literature review and input from the operator. The risk reduction strategy for herbal processing is proposed based on perspective of process safety hierarchy (PSH) as shown in Figure 1.

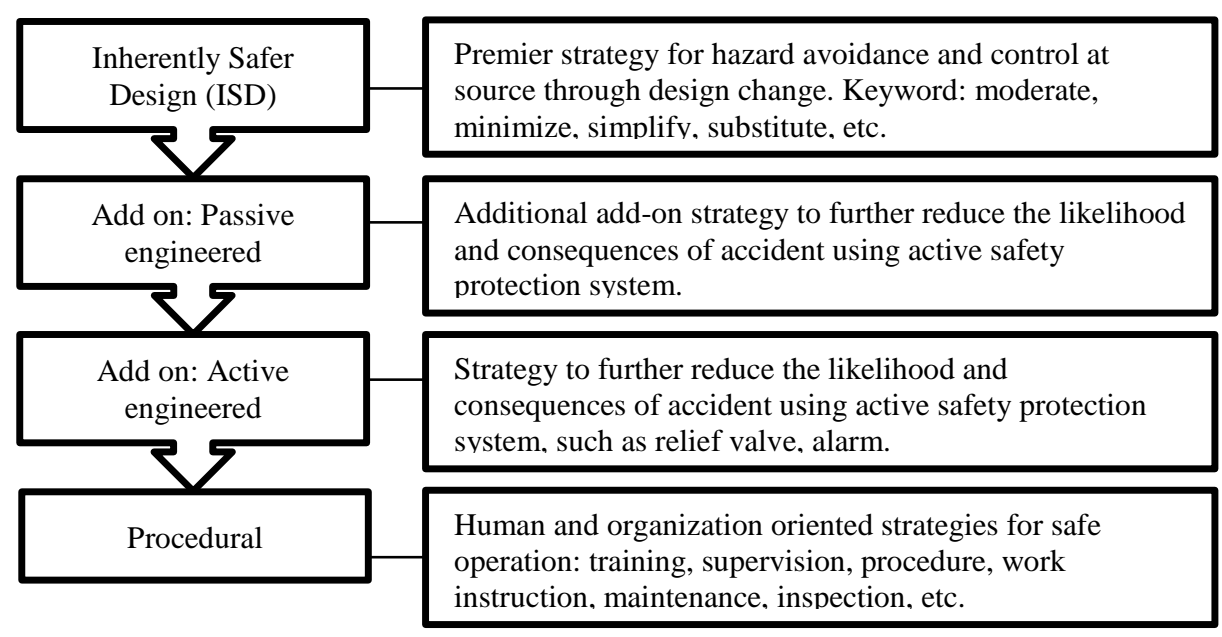

Figure 1. Process Safety Hierarchy Control [17] 


\subsection{CASE STUDY}

To understand the process, hazard and characteristics of the herbal processing, risk analysis is conducted on several case studies - Tongkat Ali, Oleoresin from Limau Purut Leaf and virgin coconut oil (VCO). The processing technology including process condition, equipment and chemical substances used will be discussed based on the process flow diagram. Based on analysis, comprehensive risk reduction strategies for herbal processing industries were proposed and ranked according to the process safety hierarchy (PSH) approach.

\subsection{Case Study 1: Tongkat Ali}

The main processing steps involved in Tongkat Ali's production is consisted of water extraction, concentration and spray drying operation. The process is operated using batch process. The root of Tongkat Ali is grinded and produced in chip form. Then, these chips are used in the extraction processing. The fresh ground Tongkat Ali root chips are sent to the pressurized vessel the extraction process using the solvent of boiled water at a temperature range of 110 to $120^{\circ} \mathrm{C}$. This boiling operation is maintained for two hours to provide sufficient time for the phytochemicals in the root chips to be leached into the extraction solvent. Upon the completion of the extraction process, the extracted liquid is filter before being pump and stored in a holding tank to vaporize undesired water in liquid product at boiling point temperature of water. After the liquid product is concentrated, it is sent for spray drying process to produce Tongkat Ali extract powder. The process flow is illustrated in Figure 2.

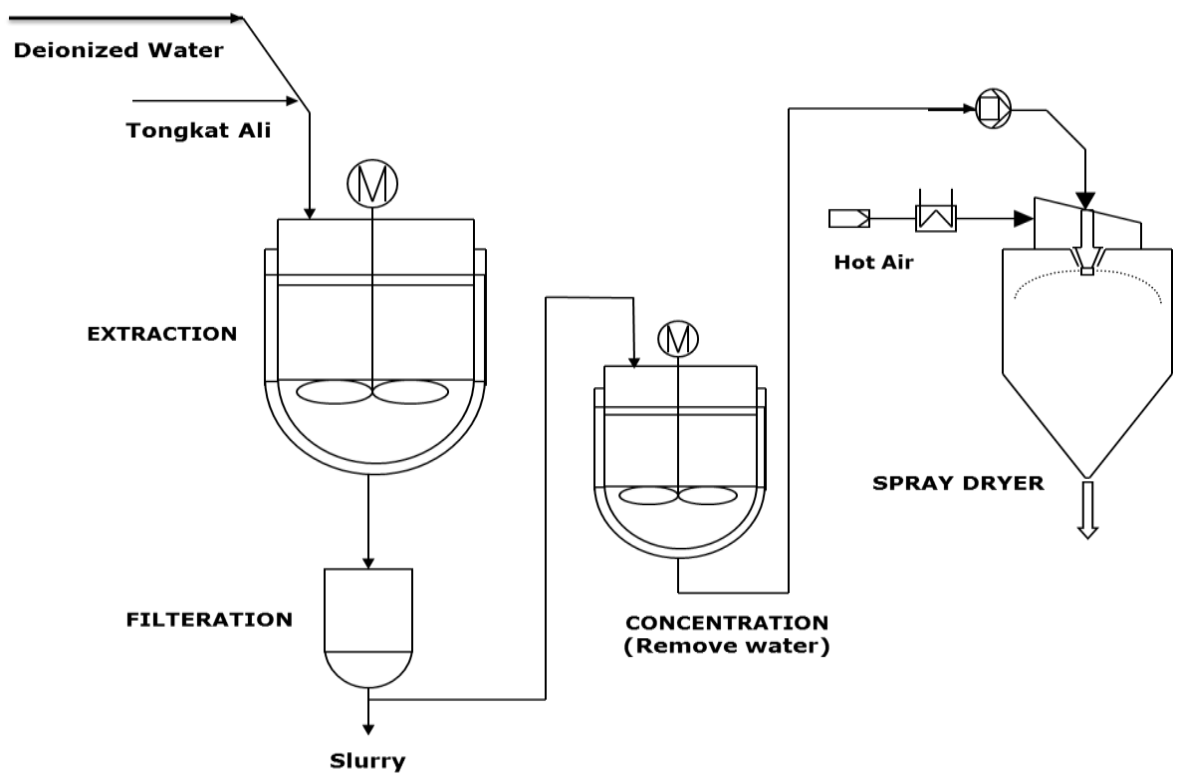

Figure 2. Tongkat Ali processing procedure

\subsection{Case Study 2: Oleoresin from Limau Purut Leaf}

The main processing steps involved in oleoresin extract production of Limau Purut are consisted of extraction, concentration, condensation process and spray drying operation. The current process is operated using a batch process. The leaf of Limau Purut is grinded and produced in chips form. Then, these chips of Limau Purut is used in the extraction process. The fresh ground Limau Purut leaf chips are sent to the pressurized vessel to be extracted using the solvent of ethanol at a temperature approximately of 70 to $80^{\circ} \mathrm{C}$. This boiling operation is maintained for 3 hours to provide sufficient time for the phytochemicals in the leaf chips to be leached into the extraction solvent. Upon the completion of the extraction process, the extracted liquid is filter before being stored in a concentration vessel to vaporize undesired ethanol in liquid product at boiling point temperature of ethanol. After the liquid product is concentrated, the product of oleoresin will be stored in holding tank. However, the vaporized ethanol will enter the condenser then condensate into liquid ethanol before been reused back at extraction unit. The process flow is illustrated in Figure 3. 


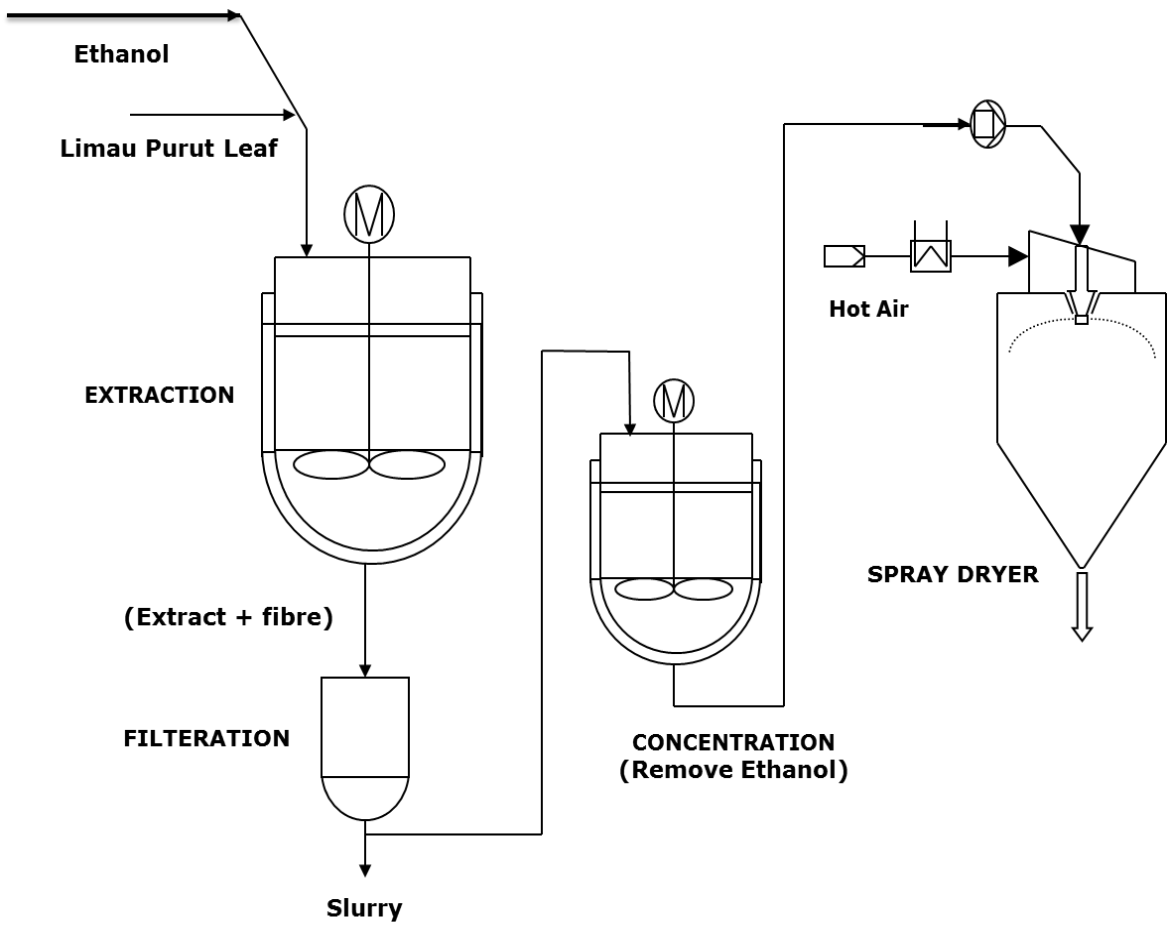

Figure 3: Oleoresin processing procedure

\subsection{Case Study 3: Virgin Coconut Oil (VCO)}

The main processing steps involved in producing VCO is extraction, two phase separation process and concentration process. The equipment involved is basically a unit of disk stack type centrifuge, extraction tank, concentration tank and heat exchanger. In VCO production, the raw material used is fresh coconut milk with capacity of 300 litre per batch. The capacity could be increased depending on the tank size. Extraction tank is equipped with a pump and agitator to ensure the better process flow and to prevent solidify issue during the extraction process. The coconut milk from extraction tank will be feed through dedicated pipeline to enter centrifuge at 4.0 litre per minute and centrifuge rotor speed controlled at $12,000 \mathrm{rpm}$. The solid discharge will be activated within 300 second interval to remove solid particle trapped inside the centrifuge basket. This step is essential to prevent solid stuck issue during the separation process.

For 300 litre coconut milk capacities, the first phase solid-liquid separation takes two hours processing time where the output is semi-finished product of VCO, water and sludge. Since the principle of centrifuge is using the density difference, the lighter phase will be at top while the heavier phase will be at below line. The density difference makes the pure VCO separated from water and solid particle. The light phase of processed VCO will be transferred into the concentration tank through dedicated pipeline. Since the process using two phase separations with single unit centrifuge, the operator is required to change the $76 \mathrm{~mm}$ to $59 \mathrm{~mm}$ disk diameter in order to obtain finer product. Hot water system is essential to purge the centrifuge from any accumulated material inside the bowl and pipeline. This step is essential to free the centrifuge bowl from solid particle and prevent contamination issue. Second phase separation will separate the virgin oil from water to obtain pure VCO. The separation process is using the same parameter as the first phase extraction where the output from the separation is pure VCO and water. Pure VCO will be transported into fine VCO tank for final product packing and distribution. In ratio, about 22 to 25 percent of fine $\mathrm{VCO}$ will be obtained from the raw coconut milk. Details of process flow diagram is presented in Figure 4. 


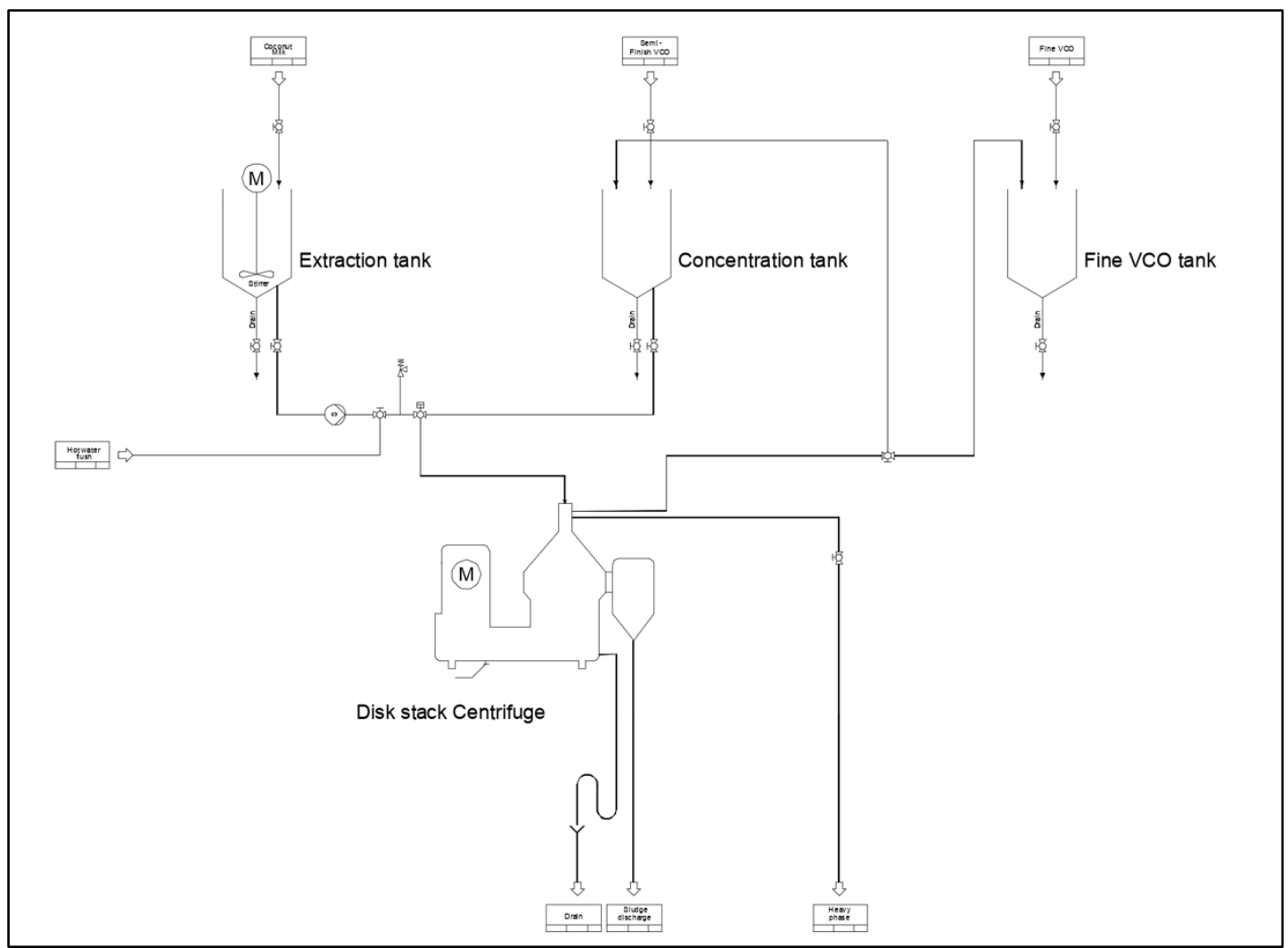

Figure 4. VCO processing procedure

\subsection{RESULT AND DISCUSSION}

The HAZOP analysis was conducted to identify the process safety hazards, possible cause and control measure to prevent unwanted event related to the herbal processing. In this study, Tongkat Ali, Limau Purut, and virgin coconut oil were among the sample used to evaluate the process safety assessment in herbal processing industry. HAZOP study was conducted at critical and designated nodes including extraction vessel, concentration vessel, spray drying unit, centrifuge, and piping. The details of the HAZOP finding are shown in Appendix A. The summary of the HAZOP finding is summarized into Table 3

Table 3. Summary of HAZOP study finding for Tongkat Ali, Limau Purut, and VCO

\begin{tabular}{|c|c|c|c|c|c|c|c|c|}
\hline \multirow{2}{*}{$\begin{array}{l}\text { Parameter } \\
\text { Guideword }\end{array}$} & \multicolumn{2}{|c|}{ Level } & \multicolumn{2}{|c|}{ Pressure } & \multicolumn{2}{|c|}{ Temperature } & \multicolumn{2}{|c|}{ Flow } \\
\hline & High & Low & High & Low & High & Low & High & Low \\
\hline \multicolumn{9}{|l|}{ Tongkat Ali } \\
\hline Extraction Unit & $\sqrt{ }$ & $\sqrt{ }$ & $\sqrt{ }$ & & $\sqrt{ }$ & $\sqrt{ }$ & & \\
\hline Concentration Unit & $\sqrt{ }$ & $\sqrt{ }$ & $\sqrt{ }$ & & $\sqrt{ }$ & $\sqrt{ }$ & & \\
\hline Spray Dryer & $\sqrt{ }$ & $\sqrt{ }$ & $\sqrt{ }$ & & $\sqrt{ }$ & $\sqrt{ }$ & $\sqrt{ }$ & $\sqrt{ }$ \\
\hline \multicolumn{9}{|l|}{ Limau Purut } \\
\hline Extraction Unit & $\sqrt{ }$ & $\sqrt{ }$ & $\sqrt{ }$ & & $\sqrt{ }$ & $\sqrt{ }$ & & \\
\hline Concentration Unit & $\sqrt{ }$ & $\sqrt{ }$ & $\sqrt{ }$ & & $\sqrt{ }$ & $\sqrt{ }$ & & \\
\hline Spray Dryer & $\sqrt{ }$ & $\sqrt{ }$ & $\sqrt{ }$ & & $\sqrt{ }$ & $\sqrt{ }$ & $\sqrt{ }$ & $\sqrt{ }$ \\
\hline \multicolumn{9}{|l|}{$\mathrm{VCO}$} \\
\hline Centrifuge & & & $\sqrt{ }$ & $\sqrt{ }$ & $\sqrt{ }$ & $\sqrt{ }$ & $\sqrt{ }$ & $\sqrt{ }$ \\
\hline Piping & & & $\sqrt{ }$ & $\sqrt{ }$ & $\sqrt{ }$ & $\sqrt{ }$ & $\sqrt{ }$ & $\sqrt{ }$ \\
\hline Tank & $\sqrt{ }$ & $\sqrt{ }$ & & & & & $\sqrt{ }$ & $\sqrt{ }$ \\
\hline
\end{tabular}


The HAZOP analysis done comes together with the risk reduction measure to prevent an accident from occurring. The possible control measure was detailed out in the HAZOP finding as shown in Appendix A. In process safety perspective, the hierarchy of control is basically based on the PSH approach. The PSH approach is a useful guide to prioritise the effectiveness of risk reduction strategies to be implemented. Based on the HAZOP study, the proposed risk reduction measures are categorised into inherently safer, active-engineering, passive-engineering and procedural. The highly effective measure is inherently safer, follow with add-on passive and active engineering while the least effective is procedural control. The outcome of propose design solution is shown in Table 4.

Table 4. Possible control method based on process safety hierarchy preference.

\begin{tabular}{|c|c|c|c|c|}
\hline \multirow{2}{*}{ Equipment } & \multicolumn{4}{|c|}{ Process Safety Hierarchy } \\
\hline & Inherently Safer & Passive & Active & Procedural \\
\hline \multirow[t]{3}{*}{$\begin{array}{l}\text { Extraction } \\
\text { Vessel/Tank }\end{array}$} & $\begin{array}{l}\text { Moderate (Robust design): } \\
\text { Vessel design to accommodate } \\
\text { maximum expected } \\
\text { temperature/ pressure. }\end{array}$ & $\begin{array}{l}\text { Install open vent or } \\
\text { overflow line to } \\
\text { containment system. }\end{array}$ & $\begin{array}{l}\text { Install adequate } \\
\text { emergency relief device } \\
\text { (relief valve, breathing } \\
\text { valve, rupture disk, etc.) }\end{array}$ & $\begin{array}{l}\text { Routine maintenance and } \\
\text { inspection on critical part } \\
\text { and fitting. }\end{array}$ \\
\hline & & & $\begin{array}{l}\text { High level alarm interlock } \\
\text { with automatic feed cut- } \\
\text { off. }\end{array}$ & $\begin{array}{l}\text { Provide SOP to stop feed } \\
\text { when level reach a high } \\
\text { point. }\end{array}$ \\
\hline & & & $\begin{array}{l}\text { Install temperature, } \\
\text { pressure indicator }\end{array}$ & \\
\hline \multirow[t]{3}{*}{ Centrifuge } & $\begin{array}{l}\text { Moderate: Operate within the } \\
\text { allowable operating and design } \\
\text { speed. }\end{array}$ & $\begin{array}{l}\text { Change from manual to } \\
\text { automatic valve for } \\
\text { reliable flow rate control. }\end{array}$ & $\begin{array}{l}\text { Install adequate } \\
\text { emergency relief device } \\
\text { (relief valve, breathing } \\
\text { valve, rupture disk, etc.) }\end{array}$ & $\begin{array}{l}\text { Routine maintenance and } \\
\text { inspection on critical part } \\
\text { and fitting. }\end{array}$ \\
\hline & $\begin{array}{l}\text { Moderate (Robust design): } \\
\text { Centrifuge design to } \\
\text { accommodate maximum } \\
\text { expected temperature/pressure } \\
\text { of feed material. }\end{array}$ & $\begin{array}{l}\text { Cooling jacket attached to } \\
\text { centrifuge bowl. }\end{array}$ & $\begin{array}{l}\text { Install high and low alarm } \\
\text { with shutdown interlock. }\end{array}$ & $\begin{array}{l}\text { Develop safety operating } \\
\text { procedure (SOP) }\end{array}$ \\
\hline & & & $\begin{array}{l}\text { Install temperature, } \\
\text { pressure, flowrate and } \\
\text { torque indicator. }\end{array}$ & $\begin{array}{l}\text { Operator shut down of } \\
\text { centrifuge when over } \\
\text { speed. }\end{array}$ \\
\hline $\begin{array}{l}\text { Spray Dryer } \\
\text { Unit }\end{array}$ & & $\begin{array}{l}\text { Install fine filter at } \\
\text { ventilation unit to prevent } \\
\text { carry-over powder } \\
\text { through ventilation. }\end{array}$ & $\begin{array}{l}\text { Interlock temperature } \\
\text { indicator with hot air feed } \\
\text { valve. If temperature too } \\
\text { high, hot air feed valve } \\
\text { cut-off. }\end{array}$ & $\begin{array}{l}\text { Routine maintenance and } \\
\text { inspection on critical part } \\
\text { and fitting. }\end{array}$ \\
\hline \multirow[t]{4}{*}{ Piping } & $\begin{array}{l}\text { Moderate (Robust design): } \\
\text { Piping designed for } \\
\text { accommodate optimize } \\
\text { operating pressure/temperature. }\end{array}$ & $\begin{array}{l}\text { Heavier walls at tees, } \\
\text { elbows, and other high } \\
\text { abrasion points. }\end{array}$ & $\begin{array}{l}\text { Install flowrate indicator } \\
\text { (FI) at inlet feed with } \\
\text { sight glass. }\end{array}$ & $\begin{array}{l}\text { Periodic maintenance } \\
\text { such as flushing, } \\
\text { blowdown, internal line } \\
\text { cleaning devices. }\end{array}$ \\
\hline & $\begin{array}{l}\text { Selection of pipe size to limit } \\
\text { velocities and material type to } \\
\text { resist erosion. }\end{array}$ & $\begin{array}{l}\text { Use jacketed or adequate } \\
\text { insulation pipe. }\end{array}$ & $\begin{array}{l}\text { Install non-return valve } \\
\text { spring type at critical line. }\end{array}$ & $\begin{array}{l}\text { Periodic inspection at } \\
\text { high wear points. }\end{array}$ \\
\hline & $\begin{array}{l}\text { Simplify: Design pipeline with } \\
\text { minimize tees and elbows. }\end{array}$ & $\begin{array}{l}\text { Securely anchor piping in } \\
\text { case of release. }\end{array}$ & $\begin{array}{l}\text { Install pressure relief } \\
\text { valve at critical point. }\end{array}$ & $\begin{array}{l}\text { Develop safety operating } \\
\text { procedure. }\end{array}$ \\
\hline & & $\begin{array}{l}\text { Use of automatic valve } \\
\text { for reliable flow rate } \\
\text { control. }\end{array}$ & $\begin{array}{l}\text { Install temperature } \\
\text { indicator (TI). }\end{array}$ & \\
\hline \multirow[t]{2}{*}{$\begin{array}{l}\text { Concentration } \\
\text { Vessel/Tank }\end{array}$} & $\begin{array}{l}\text { Moderate (Robust design): } \\
\text { Vessel design to accommodate } \\
\text { maximum expected } \\
\text { temperature/pressure of feed } \\
\text { material. }\end{array}$ & $\begin{array}{l}\text { Install open vent or } \\
\text { overflow line to } \\
\text { containment system. }\end{array}$ & $\begin{array}{l}\text { Install adequate } \\
\text { emergency relief device } \\
\text { (relief valve, breathing } \\
\text { valve, rupture disk, etc.) }\end{array}$ & $\begin{array}{l}\text { Routine maintenance and } \\
\text { inspection on critical part } \\
\text { and fitting. }\end{array}$ \\
\hline & & & $\begin{array}{l}\text { High level alarm and } \\
\text { automatic feed cut-off }\end{array}$ & $\begin{array}{l}\text { Provide SOP to stop feed } \\
\text { when level reach a high } \\
\text { point. }\end{array}$ \\
\hline
\end{tabular}


Knowledge on process safety is an important element to prevent and reduce the accident and fatality cases in workplace. Data by DOSH show that the accident rate in Malaysia is recorded at 2.88 per 1,000 workers in year 2016 [18]. The effective strategy has to develop in reducing the accident rate in Malaysia, by enhancing the knowledge related to 'safe by design' as well as safe working practice. PSM knowledge is important to bridging the gap between CPI and herbal processing industries. National Occupational Safety and Health Master Plan 2020 (OSHMP2020) has stated the importance of having good knowledge and competencies in managing risk at workplace under Strategy 2 Programme 1. The developed knowledge is expected to contribute towards the enhancement of knowledge and herbal processing technology, as well as to increase the understanding on the operational deviation, risk factor and preventing the similar accident from re-occur. This study was designed to integrate the element of process safety and design review on equipment as a tool to identify the risk factor at design stage, and propose the possible design solution to the process as well as the critical equipment.

\subsection{CONCLUSION}

Herbal processing industries are not exempted from having a risk to cause process accidents, particularly due to process failure or equipment failure scenario. Based on the process safety assessment conducted in the Tongkat Ali, Limau Purut and VCO processing industry, the findings show that the issue of process safety hazard is significant. There are few operational deviations identified which can cause harmful and lead to process accident such as fire, explosion and chemical spillage. Several risk reduction strategies have been suggested according to process safety hierarchy including inherently safer design, passive, active and procedural. Most importantly, element of knowledge 'safe by design' on process and equipment safety knowledge must be incorporated into the herbal processing technology development to create a safer working environment.

\section{References}

[1] Aziz, R. A., Sarmidi, M. R., Kumaresan, S. and Foo D. C. Y. (2005). Engineering Aspects of Herbal and Phytochemical Processing: A Malaysian Perspective.

[2] Zakaria, M. H. (2015). Review of Policies and Issues in the Malaysian Herbal Industry. Economic and Technology Management Research Centre. Selangor: MARDI.

[3] Ali, R. M., (2005). Harnessing the Cures from Malaysian Rain-Forest. Proceeding of the 6th National Congress on Genetics, 12-14 May 2005, Kuala Lumpur.

[4] Aziz, Z., \& Tey, N. (2009). Herbal medicines: Prevalence and predictors of use among Malaysian adults. Complementary Therapies in Medicine, $17,44-50$.

[5] Siti, Z., Tahir, A., Farah, A. I., \& Fazlin, S. A. (2009). Use of traditional and complementary medicine in Malaysia: a baseline study. Complementary Therapies in Medicine, 17, 292-299.

[6] Marina, A., Man, Y. C., \& Amin, I. (2009). Virgin coconut oil: emerging functional food oil. Food Science \& Technology, 481-487.

[7] Kletz, T. (2001). Learning from Accidents (Third ed.). Great Britain: Gulf Professional Publishing.

[8] Handa, S. S., Khanuja, S. P., Longo, G., \& Rakesh, D. D. (2008). Extraction Technologies for Medicinal and Aromatic Plants. Trieste, Italy: United Nations Industrial Development Organization and the International Centre for Science and High Technology.

[9] Harjo, B., Wibowo, C., and NG, K. M. (2004). Development of Natural Product Manufacturing Processes. Chemical Engineering Research and Design. 82, 1010-1028.

[10] Aziz, R. A., Sarmidi, M. R., Kumaresan, S., \& Dominic, C. (2005). Engineering Aspect of Herbal and Phytochemical Processing: A Malaysian Perspective. Universiti Teknologi Malaysia, CEPP. Johor: JURUTERA.

[11] Athimulam, A., Kumaresan, S., Foo, D. C., Sarmidi, M. R., \& Aziz, R. A. (2006). Modelling And Optimization Of Eurycoma Longifolia Water Extract Production. Food and Bioproducts Processing, 84, 139-149.

[12] Atherton, J., \& Gil, F. (2008). Incidents that Define Process Safety. . New York, USA: Wiley-AIChE.

[13] Kidam, K., Sahak, H. A., Hassim, M. H., Shahlan, S. S., \& Hurme, M. (2016). Inherently safer design review and their timing during chemical process development and design. Journal of Loss Prevention in the Process Industries, 47-58.

[14] CCPS. (1998). Guidelines For Design Solutions for Process Equipment Failures. New York, US: Center For Chemical Process Safety.

[15] Nolan, D. P. (1994). Application of HAZOP And What-If Safety Review to The Petroleum, Petrochemical and Chemical Industries. US: NOYES 
Publication.

[16] Alaei, R., Mansoori, S. A., Moghaddam, A. H., Mansoori, S. M., \& Mansoori, N. (2014). Safety Assessment Approach Of Hazard And Operability (Hazop) For Sulfur Recovery Unit Claus Reaction Furnace Package; Blower; Heat Exchanger Equipment In South Pars Gas Processing Plant. Journal of Natural Gas Science and Engineering, 271-284.

[17] Kidam, K., Hussin, N., Hassana, O., Ahmad, A., Johari, A., \& Hurme, M. (2014). Accident prevention approach throughout process design life cycle. Process Safety and Environmental Protection, 412-422.

[18] DOSH. (2017). National Occupational Accident \& Fatality Rate. Department of Occupational Safety and Health Malaysia. Putrajaya: DOSH.

[19] Center for Chemical Process Safety. (1997). Guidelines For Design Solutionsfor Process Equipment Failures. New York, US: Center For Chemical Process Safety. 
APPENDIX A

Table A1: HAZOP for Extraction Vessel (Tongkat Ali and Limau Purut)

\begin{tabular}{|c|c|c|c|}
\hline Parameter & Deviation & Possible Causes & Safeguard/Control \\
\hline \multirow[t]{8}{*}{ Level } & \multirow[t]{4}{*}{$\begin{array}{l}\text { High } \\
\text { Level }\end{array}$} & \multirow{4}{*}{$\begin{array}{l}\text { Excess deionized water } \\
\text { added in extraction } \\
\text { vessel }\end{array}$} & $\begin{array}{l}\text { Install level transmitter interlock with overflow } \\
\text { nozzle to containment system. }\end{array}$ \\
\hline & & & $\begin{array}{l}\text { High level alarm and automatic feed } \\
\text { Cut-off/isolation. }\end{array}$ \\
\hline & & & Install sight glass \\
\hline & & & $\begin{array}{l}\text { Provide SOP to stop feed when level reach a high } \\
\text { point. }\end{array}$ \\
\hline & \multirow{4}{*}{$\begin{array}{l}\text { Low } \\
\text { Level }\end{array}$} & \multirow{4}{*}{$\begin{array}{l}\text { Too little deionized } \\
\text { water added in extraction } \\
\text { vessel }\end{array}$} & Install level transmitter \\
\hline & & & Install low alarm system with shutoff mode \\
\hline & & & Maintenance of vessel \\
\hline & & & $\begin{array}{l}\text { Operating instruction to manual shutoff when low } \\
\text { level indication. }\end{array}$ \\
\hline \multirow[t]{9}{*}{ Temperature } & \multirow[t]{5}{*}{$\begin{array}{l}\text { High } \\
\text { Temperature }\end{array}$} & \multirow[t]{5}{*}{$\begin{array}{l}\text { Jacket not switch off the } \\
\text { steam after reaching } \\
\text { required temperature }\end{array}$} & $\begin{array}{l}\text { Vessel design to accommodate maximum } \\
\text { expected temperature of feed material and use } \\
\text { robust construction material. }\end{array}$ \\
\hline & & & $\begin{array}{l}\text { Install temperature transmitter to indicate the } \\
\text { temperature inside extraction vessel. }\end{array}$ \\
\hline & & & $\begin{array}{l}\text { High temperature interlock to activate cooling or } \\
\text { shutoff feeds at high temperature. }\end{array}$ \\
\hline & & & Emergency relief device and interlock shutdown. \\
\hline & & & Locate vessel to minimize exposure. \\
\hline & \multirow[t]{4}{*}{$\begin{array}{c}\text { Low } \\
\text { Temperature }\end{array}$} & \multirow[t]{4}{*}{ Low steam supply } & $\begin{array}{l}\text { Vessel design to accommodate minimum } \\
\text { expected temperature. }\end{array}$ \\
\hline & & & Low temperature alarm and shutdown interlock. \\
\hline & & & $\begin{array}{l}\text { Manual system shutdown on low temperature } \\
\text { indication. }\end{array}$ \\
\hline & & & Regular maintenance of equipment. \\
\hline \multirow[t]{6}{*}{ Pressure } & \multirow[t]{6}{*}{$\begin{array}{c}\text { High } \\
\text { Pressure }\end{array}$} & \multirow{6}{*}{$\begin{array}{l}\text { More vapour in vessel } \\
\text { due to high temperature } \\
\text { inside vessel }\end{array}$} & $\begin{array}{l}\text { Vessel design accommodating maximum supply } \\
\text { pressure and use robust construction material. }\end{array}$ \\
\hline & & & $\begin{array}{l}\text { Install pressure transmitter and pressure controller } \\
\text { to indicate the pressure inside extraction vessel. }\end{array}$ \\
\hline & & & $\begin{array}{l}\text { Interlock pressure controller with relief valve, if } \\
\text { pressure too high, relief valve will be activated } \\
\text { (venting system). }\end{array}$ \\
\hline & & & $\begin{array}{l}\text { Flow shutdown interlock activated by high } \\
\text { pressure or high flow condition. }\end{array}$ \\
\hline & & & $\begin{array}{l}\text { Emergency relief device such as pressure relief } \\
\text { valve and bursting disk. }\end{array}$ \\
\hline & & & Emergency shutdown logic. \\
\hline \multirow[t]{2}{*}{ Agitation } & \multirow[t]{2}{*}{ Less Agitation } & $\begin{array}{l}\text { Failure of motor, stirrer } \\
\text { or blades }\end{array}$ & $\begin{array}{l}\text { Immediate stop feeding on detection of loss of } \\
\text { agitation. }\end{array}$ \\
\hline & & Pump damage. & Automatic backup pump around system. \\
\hline
\end{tabular}


Table A2: HAZOP for Concentration Vessel (Tongkat Ali and Limau Purut)

\begin{tabular}{|c|c|c|c|}
\hline Parameter & Deviation & Possible Causes & Safeguard/Control \\
\hline \multirow[t]{7}{*}{ Level } & \multirow[t]{4}{*}{$\begin{array}{l}\text { High } \\
\text { Level }\end{array}$} & \multirow[t]{4}{*}{$\begin{array}{l}\text { Excess solution inside } \\
\text { the vessel }\end{array}$} & $\begin{array}{l}\text { Install level transmitter interlock with overflow } \\
\text { nozzle to containment system. }\end{array}$ \\
\hline & & & $\begin{array}{l}\text { High level alarm and automatic feed } \\
\text { Cut-off/isolation. }\end{array}$ \\
\hline & & & Install sight glass inside vessel. \\
\hline & & & $\begin{array}{l}\text { Provide SOP to stop feed when level reach a high } \\
\text { point. }\end{array}$ \\
\hline & \multirow[t]{3}{*}{$\begin{array}{l}\text { Low } \\
\text { Level }\end{array}$} & \multirow[t]{3}{*}{$\begin{array}{l}\text { Less solution inside the } \\
\text { vessel }\end{array}$} & $\begin{array}{l}\text { Install temperature transmitter to indicate the } \\
\text { temperature inside vessel. }\end{array}$ \\
\hline & & & Install sight glass inside vessel \\
\hline & & & Provide SOP \\
\hline \multirow[t]{7}{*}{ Temperature } & \multirow[t]{5}{*}{$\begin{array}{l}\text { High } \\
\text { Temperature }\end{array}$} & \multirow{5}{*}{$\begin{array}{l}\text { Jacket not switch from } \\
\text { steam to cooling water } \\
\text { after reaching required } \\
\text { temperature }\end{array}$} & $\begin{array}{l}\text { Vessel design to accommodate maximum } \\
\text { expected temperature of feed material. }\end{array}$ \\
\hline & & & $\begin{array}{l}\text { Install temperature transmitter to indicate the } \\
\text { temperature inside the vessel. }\end{array}$ \\
\hline & & & $\begin{array}{l}\text { High temperature interlock to activate cooling or } \\
\text { shutoff feeds at high temperature. }\end{array}$ \\
\hline & & & Emergency relief device and interlock shutdown. \\
\hline & & & Manual shutdown on high temperature indication. \\
\hline & \multirow[t]{2}{*}{$\begin{array}{c}\text { Less } \\
\text { Temperature }\end{array}$} & \multirow[t]{2}{*}{ Low steam supply } & $\begin{array}{l}\text { Install temperature transmitter to indicate the } \\
\text { temperature inside condenser. }\end{array}$ \\
\hline & & & Maintenance of instrumentation. \\
\hline \multirow[t]{6}{*}{ Pressure } & \multirow[t]{6}{*}{$\begin{array}{c}\text { High } \\
\text { Pressure }\end{array}$} & \multirow{6}{*}{$\begin{array}{l}\text { More vapour in vessel } \\
\text { due to high temperature } \\
\text { inside vessel. }\end{array}$} & $\begin{array}{l}\text { Vessel design accommodating maximum supply } \\
\text { pressure. }\end{array}$ \\
\hline & & & $\begin{array}{l}\text { Install pressure transmitter and pressure controller } \\
\text { to indicate the pressure inside extraction vessel. }\end{array}$ \\
\hline & & & $\begin{array}{l}\text { Interlock pressure controller with relief valve, if } \\
\text { pressure too high, relief valve will be activated } \\
\text { (venting system). }\end{array}$ \\
\hline & & & $\begin{array}{l}\text { Flow shutdown interlock activated by high } \\
\text { pressure or high flow condition. }\end{array}$ \\
\hline & & & $\begin{array}{l}\text { Emergency relief device such as pressure relief } \\
\text { valve and bursting disk. }\end{array}$ \\
\hline & & & Emergency shutdown logic. \\
\hline \multirow[t]{2}{*}{ Agitation } & \multirow[t]{2}{*}{ Less Agitation } & $\begin{array}{l}\text { Failure of motor, stirrer } \\
\text { or blades. }\end{array}$ & $\begin{array}{l}\text { Immediate stop feeding on detection of loss of } \\
\text { agitation. }\end{array}$ \\
\hline & & Pump damage. & Automatic backup pump around system. \\
\hline
\end{tabular}


Table A3: HAZOP for Spray Dryer Unit (Tongkat Ali and Limau Purut)

\begin{tabular}{|c|c|c|c|}
\hline Parameter & Deviation & Possible Causes & Safeguard/Control \\
\hline \multirow[t]{7}{*}{ Temperature } & \multirow[t]{4}{*}{$\begin{array}{c}\text { High } \\
\text { Temperature }\end{array}$} & \multirow[t]{4}{*}{$\begin{array}{l}\text { High flow of hot air } \\
\text { supply. }\end{array}$} & $\begin{array}{l}\text { Install temperature indicator to indicate inside } \\
\text { temperature of vessel. }\end{array}$ \\
\hline & & & $\begin{array}{l}\text { Interlock temperature indicator with hot air feed } \\
\text { valve. If temperature too high, hot air feed valve } \\
\text { will close. }\end{array}$ \\
\hline & & & $\begin{array}{l}\text { Interlock temperature indicator with pump of hot } \\
\text { air on ventilation unit. If the temperature too high, } \\
\text { the pump will activate to discharge the hot air } \\
\text { through ventilation. }\end{array}$ \\
\hline & & & Maintenance of instrument. \\
\hline & \multirow[t]{3}{*}{$\begin{array}{c}\text { Low } \\
\text { Temperature }\end{array}$} & \multirow{3}{*}{$\begin{array}{l}\text { Accumulated powder } \\
\text { Low flow of hot air } \\
\text { supply. }\end{array}$} & $\begin{array}{l}\text { Install temperature indicator to indicate } \\
\text { temperature inside of vessel. }\end{array}$ \\
\hline & & & $\begin{array}{l}\text { Interlock temperature indicator with hot air feed } \\
\text { valve. If temperature too low, hot air feed valve } \\
\text { will open. }\end{array}$ \\
\hline & & & Maintenance of instrument. \\
\hline \multirow[t]{4}{*}{ Pressure } & \multirow[t]{4}{*}{$\begin{array}{l}\text { High } \\
\text { Pressure }\end{array}$} & \multirow{4}{*}{$\begin{array}{l}\text { Accumulation of } \\
\text { material at feed due to } \\
\text { not fully dry will cause } \\
\text { chocking. }\end{array}$} & $\begin{array}{l}\text { Install pressure indicator to indicate pressure } \\
\text { inside of vessel. }\end{array}$ \\
\hline & & & Install bursting disk. \\
\hline & & & Emergency shutdown logic. \\
\hline & & & Increase the size of production line. \\
\hline \multirow[t]{5}{*}{ Flowrate } & \multirow[t]{3}{*}{ High Flow } & \multirow{3}{*}{$\begin{array}{l}\text { Chocking on the feed } \\
\text { line. Powder carry-out } \\
\text { through ventilation } \\
\text { system. }\end{array}$} & $\begin{array}{l}\text { Install flowrate indicator on feed line and } \\
\text { interlock with the feed line valve. }\end{array}$ \\
\hline & & & $\begin{array}{l}\text { Install flowrate indicator on product line and } \\
\text { interlock with pump. }\end{array}$ \\
\hline & & & $\begin{array}{l}\text { Install fine filter at ventilation unit to prevent } \\
\text { carry-over powder through ventilation. }\end{array}$ \\
\hline & \multirow[t]{2}{*}{ Low Flow } & \multirow{2}{*}{$\begin{array}{l}\text { Accumulated powder at } \\
\text { feed valve and } \\
\text { production line due to } \\
\text { powder not fully dried. }\end{array}$} & $\begin{array}{l}\text { Install flowrate indicator on product line and } \\
\text { interlock with hot air feed valve. If the flow is too } \\
\text { low, hot air feed will open. }\end{array}$ \\
\hline & & & Maintenance of instrument. \\
\hline
\end{tabular}


Table A4: HAZOP for Extraction Vessel (VCO)

\begin{tabular}{|c|c|c|c|}
\hline Parameter & Deviation & Possible Causes & Safeguard/Control \\
\hline \multirow[t]{4}{*}{ Level } & \multirow[t]{4}{*}{$\begin{array}{l}\text { High } \\
\text { level }\end{array}$} & \multirow[t]{4}{*}{$\begin{array}{l}\text { Excess Ethanol added in } \\
\text { extraction vessel }\end{array}$} & $\begin{array}{l}\text { Install level transmitter interlock with overflow } \\
\text { nozzle to containment system. }\end{array}$ \\
\hline & & & Install high alarm system. \\
\hline & & & Install sight glass to monitor the level. \\
\hline & & & Provide safety operating procedure (SOP) \\
\hline \multirow[t]{4}{*}{ Level } & \multirow[t]{4}{*}{$\begin{array}{l}\text { Low } \\
\text { level }\end{array}$} & \multirow[t]{4}{*}{$\begin{array}{l}\text { Too little Ethanol added } \\
\text { in extraction vessel. }\end{array}$} & $\begin{array}{l}\text { Install level transmitter guided wave radar gauge } \\
\text { for high efficiency and reliability. }\end{array}$ \\
\hline & & & Install low alarm system. \\
\hline & & & Install sight glass to monitor the level. \\
\hline & & & Provide safety operating procedure (SOP) \\
\hline \multirow[t]{9}{*}{ Temperature } & \multirow[t]{7}{*}{$\begin{array}{c}\text { More } \\
\text { Temperature }\end{array}$} & \multirow{7}{*}{$\begin{array}{l}\text { Jacket not switch off the } \\
\text { steam after reaching } \\
\text { required temperature. }\end{array}$} & $\begin{array}{l}\text { Install temperature indicator to indicate inside } \\
\text { temperature of vessel. }\end{array}$ \\
\hline & & & $\begin{array}{l}\text { Interlock temperature indicator with drainage } \\
\text { valve for steam. If the temperature too high, } \\
\text { drainage valve will open to discharge high } \\
\text { temperature steam. }\end{array}$ \\
\hline & & & $\begin{array}{l}\text { Interlock pressure indicator and pressure gauge to } \\
\text { indicate the pressure inside the extraction vessel. }\end{array}$ \\
\hline & & & Install pressure relief valve (PRV). \\
\hline & & & Install bursting disk at $2 \mathrm{Bar}$. \\
\hline & & & Emergency shutdown logic. \\
\hline & & & Maintenance of the vessel. \\
\hline & \multirow[t]{2}{*}{$\begin{array}{c}\text { Less } \\
\text { Temperature }\end{array}$} & \multirow[t]{2}{*}{ Low steam supply. } & $\begin{array}{l}\text { Install temperature indicator to indicate } \\
\text { temperature inside of vessel. }\end{array}$ \\
\hline & & & Maintenance of equipment \\
\hline \multirow[t]{3}{*}{ Agitation } & More Agitation & $\begin{array}{l}\text { Stirrer motor controller } \\
\text { fails, resulting in high } \\
\text { motor speed. }\end{array}$ & Add sensor and alarm to the stirrer. \\
\hline & Less Agitation & $\begin{array}{l}\text { Stirrer motor controller } \\
\text { fails, resulting in slow } \\
\text { motor speed. }\end{array}$ & Add sensor and alarm to the stirrer. \\
\hline & No Agitation & Pump damage. & Automatic backup pump around system. \\
\hline
\end{tabular}


Table A5: HAZOP for Centrifugal Separator Unit (VCO)

\begin{tabular}{|c|c|c|c|}
\hline Parameter & Deviation & Possible Causes & Safeguard/Control \\
\hline \multirow[t]{4}{*}{ Temperature } & \multirow[t]{4}{*}{$\begin{array}{c}\text { High } \\
\text { Temperature }\end{array}$} & \multirow{2}{*}{$\begin{array}{l}\text { Operating for long } \\
\text { duration with excessive } \\
\text { rotor speed. }\end{array}$} & $\begin{array}{l}\text { Robust design of centrifuge, construction } \\
\text { material could withstand optimum temperature. }\end{array}$ \\
\hline & & & $\begin{array}{l}\text { Operate the centrifuge at allowable operating } \\
\text { speed. }\end{array}$ \\
\hline & & \multirow{2}{*}{$\begin{array}{l}\text { No cooling system } \\
\text { attach to the bowl. }\end{array}$} & Install cooling jacket attached to centrifuge bowl. \\
\hline & & & $\begin{array}{l}\text { High temperature indicator (TI) with shutdown } \\
\text { interlock. }\end{array}$ \\
\hline \multirow[t]{5}{*}{ Pressure } & \multirow[t]{5}{*}{ High Pressure } & \multirow[t]{5}{*}{$\begin{array}{l}\text { Heat generated inside } \\
\text { the bowl. }\end{array}$} & $\begin{array}{l}\text { Robust design of centrifuge, construction } \\
\text { material could withstand optimum pressure. }\end{array}$ \\
\hline & & & $\begin{array}{l}\text { Install constant pressure valve to control the } \\
\text { pressure. }\end{array}$ \\
\hline & & & $\begin{array}{l}\text { Install pressure indicator (PI) to monitor bowl } \\
\text { temperature. }\end{array}$ \\
\hline & & & High pressure alarm with shutdown interlock. \\
\hline & & & $\begin{array}{l}\text { Add-on pressure reducer at inlet and outlet } \\
\text { centrifuge. }\end{array}$ \\
\hline \multirow[t]{4}{*}{ Speed } & \multirow{4}{*}{$\begin{array}{c}\text { High } \\
\text { Speed }\end{array}$} & \multirow{4}{*}{$\begin{array}{l}\text { Motor speed controller } \\
\text { problem. }\end{array}$} & Install speed controller. \\
\hline & & & Operate within the allowable operating speed. \\
\hline & & & Add-on torque indicator (TI). \\
\hline & & & $\begin{array}{l}\text { Automatic shutdown logic on detection of high } \\
\text { speed. }\end{array}$ \\
\hline \multirow[t]{2}{*}{ Flow } & \multirow[t]{2}{*}{$\begin{array}{l}\text { High } \\
\text { Flow }\end{array}$} & \multirow{2}{*}{$\begin{array}{l}\text { Failure of manual ball } \\
\text { valve, variable area feed } \\
\text { inlet. }\end{array}$} & $\begin{array}{l}\text { Change from manual to automatic valve for } \\
\text { reliable flow rate control. }\end{array}$ \\
\hline & & & $\begin{array}{l}\text { Install flowrate indicator (FI) at inlet feed with } \\
\text { sight glass. }\end{array}$ \\
\hline
\end{tabular}

Table A6: HAZOP for Extraction and concentration tank (VCO)

\begin{tabular}{|c|c|c|c|}
\hline Parameter & Deviation & Possible Causes & Safeguard/Control \\
\hline \multirow[t]{8}{*}{$\overline{\text { Level }}$} & \multirow[t]{5}{*}{$\begin{array}{l}\text { High } \\
\text { Level }\end{array}$} & \multirow[t]{3}{*}{$\begin{array}{l}\text { Intake feed valve } \\
\text { problem. }\end{array}$} & $\begin{array}{l}\text { Change from manual to automatic valve for } \\
\text { reliable flow rate control. }\end{array}$ \\
\hline & & & Install overflow valve. \\
\hline & & & High level alarm. \\
\hline & & \multirow[t]{2}{*}{$\begin{array}{l}\text { Operator fail to turn off } \\
\text { the feed valve. }\end{array}$} & $\begin{array}{l}\text { Emergency stop button to stop feed immediately } \\
\text { when level reaches a high point set. }\end{array}$ \\
\hline & & & Sight glass to see the material level inside tank. \\
\hline & \multirow[t]{3}{*}{$\begin{array}{l}\text { Low } \\
\text { Level }\end{array}$} & \multirow[t]{3}{*}{$\begin{array}{l}\text { Intake feed valve } \\
\text { problem, feed shortage. }\end{array}$} & $\begin{array}{l}\text { Change from manual to automatic valve for } \\
\text { reliable flow rate control. }\end{array}$ \\
\hline & & & Low level alarm. \\
\hline & & & Sight glass to see the material level inside tank. \\
\hline \multirow[t]{3}{*}{ Agitation } & \multirow[t]{3}{*}{$\begin{array}{l}\text { Less } \\
\text { Agitation }\end{array}$} & \multirow[t]{2}{*}{ Stirrer motor failure. } & $\begin{array}{l}\text { Immediate stop feeding on detection of loss of } \\
\text { agitation. }\end{array}$ \\
\hline & & & Regular inspection and maintenance program. \\
\hline & & Pump failure. & Automatic backup pump in standby. \\
\hline
\end{tabular}


Table A7: HAZOP for Piping and Piping equipment

\begin{tabular}{|c|c|c|c|}
\hline Parameter & Deviation & Possible Causes & Safeguard/Control \\
\hline \multirow[t]{9}{*}{ Flow } & \multirow[t]{5}{*}{ High Flow } & \multirow{5}{*}{$\begin{array}{l}\text { Failure of manual ball } \\
\text { valve, variable area feed } \\
\text { meter. }\end{array}$} & $\begin{array}{l}\text { Change from manual to automatic valve for } \\
\text { reliable flow rate control. }\end{array}$ \\
\hline & & & $\begin{array}{l}\text { Use robust pipe design with optimize pipe size } \\
\text { and material construction. }\end{array}$ \\
\hline & & & $\begin{array}{l}\text { Install flowrate meter at inlet feed with sight } \\
\text { glass. }\end{array}$ \\
\hline & & & $\begin{array}{l}\text { Heavier walls at tees, elbows, and other high } \\
\text { abrasion points. }\end{array}$ \\
\hline & & & Securely anchor piping. \\
\hline & \multirow[t]{2}{*}{ No Flow } & \multirow{2}{*}{$\begin{array}{l}\text { Blockage due to solid } \\
\text { deposition. }\end{array}$} & Design pipeline with minimize tees and elbows. \\
\hline & & & Install sufficient pump for better flow. \\
\hline & \multirow[t]{2}{*}{ Reverse Flow } & \multirow{2}{*}{$\begin{array}{l}\text { Pressure difference } \\
\text { inside the pipeline or } \\
\text { joint. }\end{array}$} & $\begin{array}{l}\text { Install non-return valve spring type at critical } \\
\text { line. }\end{array}$ \\
\hline & & & $\begin{array}{l}\text { Manual isolation on detection of low differential } \\
\text { pressure }\end{array}$ \\
\hline \multirow[t]{2}{*}{ Temperature } & \multirow{2}{*}{$\begin{array}{c}\text { High } \\
\text { Temperature }\end{array}$} & \multirow{2}{*}{$\begin{array}{l}\text { Unstable heat generated } \\
\text { by the heat exchanger. }\end{array}$} & Use jacketed or adequate insulation pipe \\
\hline & & & Temperature indicator $(\mathrm{TI})$. \\
\hline \multirow[t]{5}{*}{ Pressure } & \multirow[t]{5}{*}{ High Pressure } & \multirow[t]{3}{*}{$\begin{array}{l}\text { Design of the piping } \\
\text { which involved much } \\
\text { tees and elbow. }\end{array}$} & $\begin{array}{l}\text { Piping designed for accommodate optimize } \\
\text { operating pressure. Adequate safety factor } \\
\text { implements. }\end{array}$ \\
\hline & & & Securely anchor piping in case of release. \\
\hline & & & Install pressure relief valve \\
\hline & & \multirow[t]{2}{*}{$\begin{array}{l}\text { Blockage due to solid } \\
\text { deposition. }\end{array}$} & $\begin{array}{l}\text { Periodic maintenance such as flushing, } \\
\text { blowdown, internal line cleaning devices. }\end{array}$ \\
\hline & & & Install pressure relief valve \\
\hline \multirow[t]{2}{*}{ Composition } & \multirow[t]{2}{*}{$\begin{array}{l}\text { Wrong } \\
\text { Composition }\end{array}$} & \multirow[t]{2}{*}{$\begin{array}{l}\text { Error in operating the } \\
\text { manual ball valve. }\end{array}$} & $\begin{array}{l}\text { Automatic ball valve system to replace manual } \\
\text { valve. }\end{array}$ \\
\hline & & & Dedicated pipeline with colour indicator. \\
\hline
\end{tabular}

